\title{
Pemanfaatan Citrus aurantifolia (Christm. et Panz.) sebagai Bahan Pangan dan Obat serta Bioaktivitas
}

\author{
Marina Silalahi \\ *e-mail: marina_biouki@yahoo.com;marina.silalahi@uki.ac.id \\ Prodi Pendidikan Biologi, Fakultas Keguruan dan Ilmu Pendidikan \\ Universitas Kristen Indonesia
}

\begin{abstract}
Lime or Citrus aurantifolia (CA) is a type of medicinal plant that has long been used by local communities in Indonesia. Besides being used as traditional medicine, the fruit is also used for a variety of food or drinks. The use of plants as traditional medicine is related to the bioactivity and content of secondary metabolites. This study aims to explain the relationship between the use of CA as traditional medicine and its bioactivity. The method used is a literature review published online on Google Scholar and also scientific journals about CA using CA keywords, CA uses, and CA biaoctivities, then synthesized so as to obtain comprehensive information. In ethnobotany CA is used to treat fever, sauna ingredients, cough medicines, to increase stamina, overcome hypertension, and anti-cholesterol. Various researchers have successfully demonstrated the bioactivity of CAs which are anti cholesterol, antimicrobial, antioxidant, anti hypertension, anti osteoporosis and anti cancer. Essential oils found in the leaves and fruit are compounds responsible for their bioactivity. The ability of $\mathrm{CA}$ as an antimicrobial can be very potential to be developed for health as well as a natural food preservative.
\end{abstract}

Keywords: Citrus aurantifolia, essential oil and anti-microbial

\begin{abstract}
ABSTRAK
Jeruk nipis atau Citrus aurantifolia (CA) merupakan salah jenis tumbuhan obat yang telah lama digunakan oleh masyarakat lokal di Indonesia. Selain digunakan sebagai obat tradisional, buahnya juga digunakan untuk berbagai bahan makanan atau minuman. Pemanfaatan tumbuhan sebagai obat tradisional berhubungan dengan bioaktivitas dan kandungan metabolit sekundernya. Kajian ini bertujuan untuk menjelaskan hubungan pemanfaatan CA sebagai obat tradisional dan bioaktivitasnya. Metode yang digunakan adalah kajian literatur yang terbit secara online di google scholar dan juga jurnal ilmiah tentang CA dengan menggunakan kata kunci CA, uses $\mathrm{CA}$, dan biaoctivities CA, kemudian disintesakan sehingga diperoleh informasi yang konfrehensif. Secara etnobotani CA digunakan untuk mengatasi demam, bahan sauna, obat batuk, untuk meningkatkan stamina, mengatasi hipertensi, dan anti kolesterol. Berbagai peneliti telah berhasil menunjukkan bioaktivitas CA yaitu anti kolesterol, anti mikroba, anti oksidan, anti hipertensi, anti osteoporosis dan anti kanker. Essensial oil yang banyak ditemukan pada bagian daun dan buah merupakan senyawa bertanggung jawab untuk bioaktivitasnya. Kemampuan CA sebagai antimikroba dapat sangat potensial dikembangkan untuk kesehatan sekaligus sebagai pengawet makanan alami.
\end{abstract}

Kata Kunci: Citrus aurantifolia, essensial oil dan anti mikroba 


\section{PENDAHULUAN}

Jeruk merupakan salah salah satu kelompok tumbuhan yang memiliki multifungsi yang banyak digunakan sebagai bahan obat maupun sebagai bahan pangan. Dalam taksonomi tumbuhan, jeruk dikelompokkan pada Genus Citrus dan Famili Rutaceae. Oleh masyarakat lokal Indonesia, untuk membedakan satu jenis jeruk dengan jenis jeruk lainnya ditambahkan dengan kata kedua yang dihubungkan dengan sifat atau karakter terutama bagian buahnya. Secara empirik terlihat bahwa buah jeruk memiliki variasi dalam bentuk, ukuran, aroma, permukaan dan warna kulit buah.

Berbagai jenis jeruk mudah kita temukan di berbagai pasar modern maupun tradisional dan banyak dibudidayakan di pekarangan maupun di kebun. Diperkirakan Citrus telah dibudidayakan sejak ribuan tahun lalu dan diyakini sebagai jenis tumbuhan yang kaya akan Vitamin C (Okwu dan Emenike, 2006). Beberapa jenis jeruk yang banyak di perjual-belikan di pasar antara lain jeruk bali (Citrus maxima), jeruk manis (Citrus sinensis), jeruk lemon (Citrus $x$ lemon), jeruk purut (Citrus hisryx), jeruk nipis (Citrus aurantifolia), dan jeruk limau (Citrus amblycarpa). Fungsi utama dari setiap jeruk bervariasi misalnya jeruk bali dan jeruk medan digunaka sebagai sumber buah segar, sedangkan jeruk purut digunakan dalam acara ritual. Akar dari berbagai jenis jeruk (Citrus spp) digunakan oleh sub-etnis Batak Simalungun sebagai bahan ramuan tinuktuk (ramuan untuk meningkatkan stamina) (Silalahi et al. 2015), sedangkan buah dan daun Citrus spp digunakan sebagai bahan utama sauna tradisional etnis Batak (Silalahi dan Nisyawati 2019).

Jeruk nipis atau dalam nama ilmiah dikenal dengan nama Citrus aurantifolia (CA) merupakan jenis jeruk yang digunakan sebagai bahan masakan, dan juga sebagai obat tradisional. Dalam pengolaan makanan, CA digunakan untuk menghilangkan bau amis pada pengolahan ikan dan memberi aroma segar. Bila dibanding dengan jenis Citrus lainnnya, CA memiliki fungsi yang lebih banyak. Dalam pengobatan tradisional buah CA banyak digunakan sebagai obat batuk atau ganggunan saluran pernapasan. Oleh etnis Batak CA dikenal dengan rimo bunga, (Karo, Phakpak), utte bunga (Mandailing, Toba) (Silalahi 2014). Tumbuhan ini mudah ditemukan di lingkungan sekitar terutama di pekarangan dan juga dapat digunakan sebagai salah satu tumbuhan yang dapat menambah income keluarga (Silalahi et al. 2018).

Taiz and Zeinger (2006) menyatakan bahwa berdasarkan proses pembentukannya metabolit sekunder pada tumbuhan dibedakan menjadi alkaloid, phenolik dan terpenoid. Salah satu kelompok terpenoid yang banyak dimanfaatkan sebagai obat adalah essential oil. Analisis kromatografi gasspektrometri massa mengungkapkan adanya monoterpendan sesquiterpen sebagai komponen yang paling umum pada daun dan buah CA (Loizzo et al. 2012). Senyawa ini merupakan senyawa yang mudah menguap sehingga dikenal juga sebagai volatil oil, oleh karena itu senyawa ini juga menghasilkan aroma khas. Silalahi dan Nisayawati (2019) menyatakan bahwa dalam pengobatan tradisional etnis Karo menggunakan berbagai jenis Citrus sebagai bahan utama dalam pembuatan oukup (sauna tradisional etnis Batak Karo) yang menghasilkan aroma terapi sehingga memberi efek relaksasi. Senyawa monoterpenoid yang bersifat volatil pada CA merupakan senyawa dominan berupa limonene, $\gamma \quad$-terpinene, $\beta$-pinene, 
geranial, neral, neryl acetate dan geranyl acetate (Craske et al. 2005).

Pemanfaatan bahan alami dalam pengobatan dianggap lebih aman dibandingkan dengan bahan sintetis, walaupun demikian perlu dipahami pemakian dalam dosis yang tepat sehingga dapat meminimalkan efek sampingnya. Chunlaratthanaphorn et al. (2007) menyatakan bahwa pemberian secara oral ekstrak akar CA dengan dosis 300,600 dan $1.200 \mathrm{mg} / \mathrm{kg}$ berat badan selama 90 hari (uji subkronik) tidak menunjukkan toksis. Walaupun demikian pemberian ekstrak secara oral dengan konsentrasi $1.200 \mathrm{mg} / \mathrm{kg} / \mathrm{hari}$ ekstrak CA pada tikus jantan dan betina mengakibatkan peningkatan enzim liver namun tetap dalam kisaran normal dan tetapi tidak menghasilkan perubahan histopatologis yang signifikan pada organ internal (Chunlaratthanaphorn et al. 2007). Oleh karena pemahaman dan informasi mengenai bioaktivitas CA sangat perlu karena pemakaian pada dosis yang berlebihan dapat bersifat toksik.

\section{BAHAN DAN METODE}

Penelitian ini dilakukan berdasarkan kajian literatur pada berbagai buku, artikel dan penelitian ilmiah yang terbit secara online maupun offline. Berbagai sumber informasi yang digunakan seperti google scholar, pubmed dengan menggunakan kata kunci Citrus aurantifolia, bioactivities Citrus auritifolia, uses of Citrus aurantifolia. Artikel, buku atau hasil penelitian yang diperoleh disintesakan sehingga dapat menjelasakan botani, manfaat dan bioaktivitas dari Citrus aurantifolia.

\section{HASIL DAN PEMBAHASAN}

\section{Botani Citrus aurantifolia \\ Rutaceae merupakan salah satu famili yang speciesnya banyak}

dimanfaatkan sebagai bahan pangan maupun bahan obat tradisional. Famili ini ditandai dengan adanya essential oil sehingga mudah dikeali dari aromanya. Jeruk nipis atau dengan nama ilmiah Citrus auriintifolia merupakan salah satu jenis yang banyak digunakan sebagai obat tradisional.

Citrus aurantifolia memiliki habitus berupa semak hingga pohon kecil, biasanya dengan banyak cabang dan berduri. Daun tersusun spiral dengan tipe majemuk beranak daun tunggal, tangkai pendek, helaian anak daun berbentuk jorong atau bundar telur melebar, 5-8 × 2-4 cm, dengan bentuk tepi membundar, tepi mengerut dengan ujung yang tumpul dan terkadang bertusuk. Bunga muncul soliter atau terangkai dalam perbungaan dengan jumlah bunga maksimal hingga 7 . Bunga bersimetri banyak dengan kelopak menyerupai mangkuk, segmen 4 atau 5, mahkota umumnya dengan segmen berjumlah 5 atau jarang 4, berwarna putih dengan panjang $1-1.2 \mathrm{~cm}$ dan cenderung mendaging, benang sari antara 20 hingga 25 dengan bakal buah berbentuk bulat. Buah berwarna kuning kehijauan, bentuk bervariasi dari bulat, jorong atau bulat telur sungsang, dengan diameter berkisar antara 4-5 cm, halus dengan banyak kelenjar minyak, sarkokarp dengan 9-12 segmen, sangat masam. Biji berbentuk bulat telur dengan kotiledon warna putih susu (Zhang and Mabberley 2008).

CA merupakan buah komersial yang telah lama dibudidayakan diberbagi negara. Buah CA memiliki keasaman yang berbeda-beda yang diduga terjadi karena perbedaan variasi genetiknya. Kumar et al. (2013) menganalisa 6 varietas CA dengan menggunakan sepuluh primer random amplified polymorphic DNA (RAPD). Rata-rata kesamaan genetik dalam 6 varietas tersebut sebesar 60,5\% (Kumar et al. 2013). 


\section{Manfaat}

Citrus aurantifolia telah lama dimanfaatkan dalam berbagai pengobatan tradisional baik sebagai bahan tambahan maupun sebagai bahan utama. Secara empirik terlihat bahwa oleh pedagang jamu gendong (jamu segar yang dijajahkan dengan cara mengendong) selalu menggunakan jeruk nipis untuk memberi efek yang menyegarkan sekaligus berfungsi untuk pelarut berbagai senyawa yang sulit larut dalam air seperti curcumin. Sub-etnis Batak Simalungun di Sumatera Utara menggunakan CA sebagai salah satu pengawet ramuan dan diyakini dapat meningkatkan stamina (Silalahi et al. 2015). Air perasan buah CA dapat digunakan untuk mengatasi jerawat dan juga untuk mengobati luka sehingga tidak terjadi abses (Razak et al. 2013). Jus lemon (Citrus limon) dan jeruk nipis (Citrus aurantifolia) dalam pengobatan tradisional digunakan untuk untuk mengatasi hipertensi dan penyakit kardiovaskular lainnya (Oboh et al. 2015). Berbagai peneliti telah membuktikan bioaktivitas ekstrak buah CA sebagai anti kolesterol (Yaghmaie et al. 2011).

\subsection{Anti Kolesterol}

Kelebihan kandungan kolesterol di dalam plasma darah merupakan senyawa salah satu penyebab gangguan kardiovaskuler, oleh sebab itu kadarnya di dalam darah perlu dikendalikan. Senyawa yang dapat menurunkan kadar kolesterol darah disebut dengan senyawa anti kolesterol. Penelitian bahan alam sebagai anti kolesterol terus dilakukan termasuk CA (Yaghmaie et al. 2011; Oboh et al. 2015). Jus CA memiliki sifat hipokolesterolemia (Oboh et al. 2015). Pemberian essential oil dari kulit buah CA pada tikus Wistar dengan dosis 25, 50, dan $100 \mu \mathrm{L} / \mathrm{kg}$ mempengaruhi kadar trigliserida dan kolesterum serum darah tikus, namun tikus yang diberi 50 dan $100 \mu \mathrm{L} / \mathrm{kg}$ menunjukkan penurunan trigliserida, kolesterol dan LDL secara signifikan $(p<0,01)$ sehingga disarankan sebagai bahan untuk menurunkan resiko penyakit kardiovaskular (Yaghmaie et al. 2011). Pemberian jus CA pada tikus yang diberi makan diet tinggi kolesterol menyebabkan penurunan yang signifikan dalam kadar kolesterol total plasma, trigliserida, dan kolesterol LDL dan peningkatan kadar kolesterol HDL plasma. Penghambatan aktivitas ACE secara in vitro dan in vivo efek hipokolesterolemia jus dapat menjelaskan penggunaan jus dalam mengatasi penyakit kardiovaskular (Oboh et al. 2015). Jus jeruk nipis mempengaruhi aktivitas enzim angiotensin-1-converting (ACE) secara in vitro dan juga memiliki sifat hipokolesterolemia. Jus lemon memiliki kandungan fenol total yang lebih tinggi $(64,5 \mathrm{mg} / \mathrm{l})$, sedangkan jus jeruk nipis memiliki kandungan flavonoid total yang lebih tinggi (29,5 $\mathrm{mg} / \mathrm{l})$. Kedua jus menghambat aktivitas ACE dan aktivitas tersebut tergantung dosis (Oboh et al. 2015). 

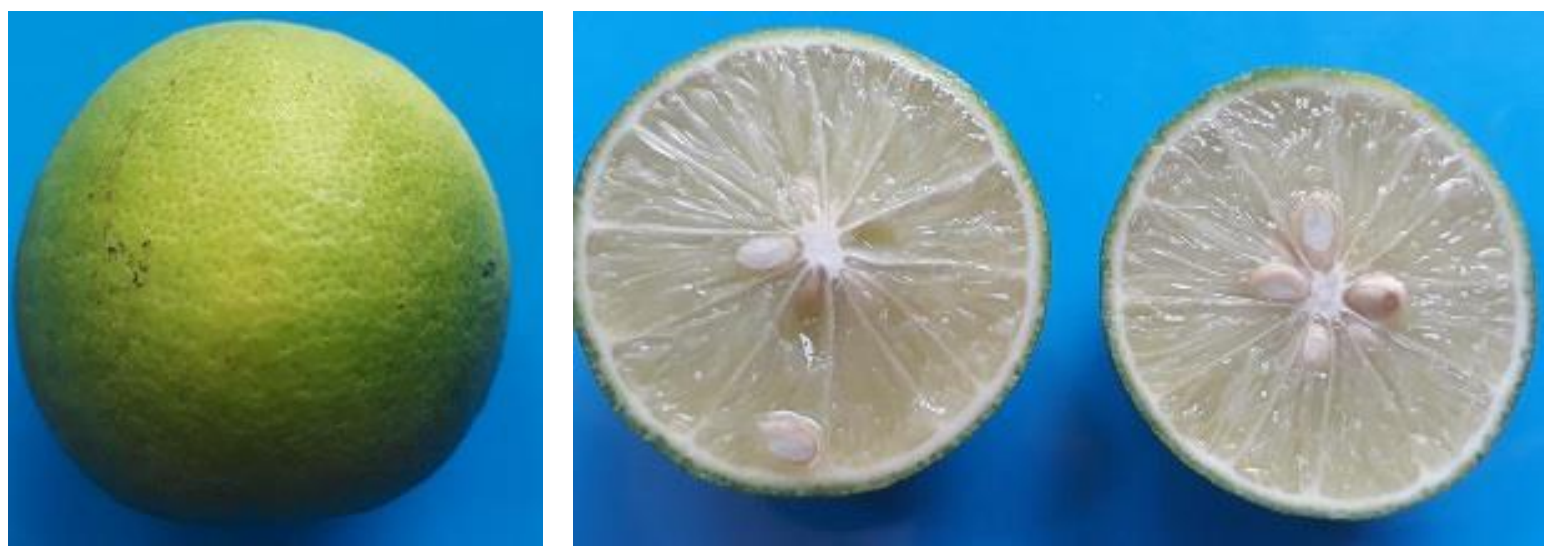

Gambar 1. Citrus aurantifolia. Kiri. Buah. Kanan. Sayatan Melintang dari buah

(Dokumentasi Pribadi)

\subsection{Anti Bakteri}

Mikroba patogen dapat mengakibatkan berbagai penyakit pada manusia. Untuk mengatasi penyakit yang disebabkan mikroba dapat digunakan senyawa anti mikroba. Senyawa anti mikroba merupakan senyawa yang menghambat pertumbuhan atau mengakibatkan kematian mikroba. Ekstrak CA memiliki spektrum yang luas sebagai anti mikroba patogen pada manusia (Taiwo et al. 2007). Ekstrak CA menghambat pertumbuhan Staphylococcus aureus (Razak et al. 2013; Onyeagba et al. 2004), Escherichia coli (Oboh and Abulo 1997; Taiwo et al. 2007; Onyeagba et al. 2004) Staphylococcus sp. (Oboh and Abulo 1997; Taiwo et al. 2007), Salmonella spp (Oboh and Abulo 1997; Onyeagba et al. 2004), Bacillus subtilis, Streptococcus faecalis (Oboh and Abulo 1997), Klebsiella sp., Proteus sp. (Taiwo et al. 2007), dan Bacillus spp. (Onyeagba et al. 2004). Kemampuan ekstrak CA menghambat pertumbuhan Bacillus subtilis, Salmonella sp., Escherichia coli, Streptococcus faecalis dan Staphylococcus menunjukkan bahwa ekstrak CA sangat potensial digunakan untuk mengasi gangguan saluran pencernaan dan demam (Oboh and Abulo 1997), sedangkan kemampuan menghambat Staphylococcus aureus berpotensi dalam bidang kecantikan terutama sebagai anti jerawat (Razak et al. 2013) dan luka.

Jus buah dan kulit buah CA memiliki aktivitas anti mikroba yang bersifat patogen seperti Staphylococcus aureus, Staphylococcus aureus, Salmonella paratyphi, Shigella flexnerii, Streptococcus faecalis, Citrobacter spp, Serratia spp, Klebsiella pneumoniae, Pseudomonas aeruginosa, Escherichia coli, and Escherichia coli (Aibinu et al. 2007). Jus buah dan kulit buah CA memiliki aktivitas anti mikroba yang bersifat patogen serta bakteri anaerob seperti Bacteroides spp., Porphyromonas spp, dan Clostridium spp. (Aibinu et al. 2007)

Bioaktivitas ekstrak CA sebagai anti mikroba dipengaruhi oleh berbagai faktor antara lain jenis mikroba, konsentrasi, waktu kontak (Razak et al. 2013) dan senyawa yang digunakan untuk ekstraksi. Air perasan CA memiliki daya hambat terhadap pertumbuhan bakteri Staphylococcus aureus dengan berbagai konsentrasi yaitu 25\%, 50\%, $75 \%$, dan $100 \%$. Konsentrasi dan lama waktu kontak berbanding lurus daya hambat air perasan CA terhadap bakteri Staphylococcus aureus (Razak et al. 2013). Rata-rata diameter zona hambat Staphylococcus sp., Escherichia coli, Klebsiella sp., Proteus sp., dan Pseudomonas sp. yang diberi pemberian ektrak CA dengan konsentrasi $5 \mu \mathrm{L}$ 
sebesar 10, 12, 11, 17, dan $16 \mathrm{~mm}$ secara berurutan (Taiwo et al. 2007). Hal yang hampir sama ditemukan oleh Oboh and Abulo (1997) bahwa ekstrak etanol CA memiliki rata rata zona hambat sebesar $14,2 \mathrm{~mm} ; 9,2 \mathrm{~mm} ; 8,5 \mathrm{~mm} ; 8,1 \mathrm{~mm} ; 7,2$ mm pada bakter Bacillus subtilis, Salmonella sp., Escherichia coli, Streptococcus faecalis dan Staphylococcus secara berurutan (Oboh and Abulo 1997). Bakteri anaerob dan bakteri Gram-positif rentan terhadap semua ekstrak estrak etanol dan air dari buah dan kulit buah CA dengan konsentrasi penghambatan minimum (MIC) mulai dari $32 \mathrm{mg} / \mathrm{ml} \mathrm{-} 128 \mathrm{mg} / \mathrm{ml}$ (Aibinu et al. 2007). Bakteri Gramnegatif memiliki MIC mulai dari 64 $\mathrm{mg} / \mathrm{ml}-512 \mathrm{mg} / \mathrm{ml}$. Konsentrasi bakterisida minimum (MBC) berkisar antara $32 \mathrm{mg} / \mathrm{ml}$ hingga $512 \mathrm{mg} / \mathrm{ml}$ tergantung pada isolat dan ekstraksi pelarut (Aibinu et al. 2007).

Tuberkulosis merupakan salah satu jenis penyakit yang sulit disembuhkan hingga saat ini, yang disebabkan oleh bakteri Gram positif dari jenis Mycobacterium tuberculosis. Sandoval-Montemayor et al. (2012) menyatakan bahwa ekstrak kulit buah CA menghambat pertumbuhan Mycobacterium tuberculosis H37Rv yang sensitif maupun yang resisten terhadap isoniazid, streptomisin dan etambutol. Bioaktivitas ekstrak heksana CA berhubungan dengan senyawa 5,8-dimethoxypsoralen dan asam palmitat merupakan senyawa dengan aktivitas yang paling aktif sebagai anti mikrobakteri (Sandoval-Montemayor et al. 2012). Senyawa tersebut memiliki aktivitas (MICs $=25-50 \mu \mathrm{g} / \mathrm{mL}$ ) (Sandoval-Montemayor et al. 2012).

\subsection{Antioksidan}

Penelitian tentang tumbuhan sebagai sumber senyawa antioksidan terus dilakukan. Senyawa antioksidan merupakan senyawa yang digunakan untuk menangkal atau menghambat radikal bebas. Berbagai ahli menyatakan bahwa radikal bebas secara langsung maupun tidak langsung berhubungan dengan berbagai penyakit seperti kanker, diabetes mellitus dan juga stroke dan alzaemir. Radikal bebas telah terlibat dalam perkembangan beberapa penyakit manusia seperti arterosklerosis, diabetes mellitus, peradangan kronis, gangguan neurodegeneratif, dan beberapa jenis kanker tertentu (Halliwell 1996). Degenerasi sel oksidatif terkait dengan berbagai penyakit neurodegeneratif seperti penyakit Alzheimer (Loizzo et al. 2012). Di laboratorium aktivitas antioksidan dapat dievaluasi dengan menggunakan aktivitas pembersihan radikal bebas dari 1, 1-diphenyl-2picrylhydrazyl radical (DPPH) dan total antioxidant capacity (TAC) (Kumari et al. 2013). Oleh karena itu komsumsi senyawa antioksidan merupakan salah satu pencegahan dari penyakit tersebut. Senyawa fenolik merupakan senyawa yang telah terbukti sebagai antioksidan termasuk di dalamnya flavonoid. Ekstrak CA mengandung flavonoid berupa apigenin, rutin, quercetin, kaempferoldan nobiletin (Loizzo et al. 2012), oleh karena itu diyakini memilki aktivitas sebagai antioksidan.

Penelitian tumbuhan sebagai antioksidan alami tetap menarik untuk menggantika antioksidan sintetik sehingga diperoleh berbagai sumber alternatif antioksidan baru termasuk CA (Loizzo et al. 2012). Penelitian bioaktivitas CA sebagai antioksidan telah banyak dilaporkan. Senyawa phenolik merupakan kelompok senyawa yang telah terbukti sebagai antioksidan. Jus buah mentah maupun buah matang CA memiliki aktivitas sebagai antioksidan secara in-vitro. Jus buah CA yang mentah (muda) menunjukkan aktivitas lebih tinggi dalam pemulungan dibandingkan dengan jus buah yang matang (Kumari et al. 2013). Berkurangnya aktivitas buah yang sudah matang diduga berhubungan dengan semakin berkurangnya 
kandungan asam askorbat pada buah yang matang. Kumari et al. (2013) menyatakan bahwa jus buah CA yang belum matang dapat memberikan perlindungann terhadap kerusakan akibat radikal bebas.

Ekstrak metanol dari kulit dan daun CA menunjukkan aktivitas pemulungan radikal terkuat. Tren serupa diamati dengan kemampuan reduksi, dengan nilai dari 112,1 menjadi 146,0 $\mu$ mol L ${ }^{-1} \mathrm{Fe}(\mathrm{II}) \mathrm{g}^{-1}$. Fraksi n-heksan dari kulit dan daun CA menunjukkan aktivitas penghambatan asetilkolinesterase yang baik dengan nilai IC50 dalam kisaran 91,4-107,4 $\mu \mathrm{gmL}^{-1}$ (Loizzo et al. 2012).

\subsection{Anti Osteoporosis}

Osteoporosis merupakan salah satu gangguan pada tulang yang mengakibatkan tulang mudah patah karena kekurangan kalsium dan fosfor. Pada umumnya osteoporosis banyak terjadi pada manusia usia lanjut dan pada wanita banyak terjadi setelah menopause. Berbagai bahan alam diyakini dapat meningkatkan kandungan mineral tulang atau agen antiosteoporotik termasuk CA. Shalaby et al. (2011) menyatakan bahwa ekstrak buah CA memiliki aktivitas sebagai anti osteoporosis yang telah diuji pada tikus. Lebih lanjut dikatakannya bahwa pemberian ekstrak CA meningkat kandungan mineral tulang trabekuler dan kepadatan mineral tulang tibia, meningkatkan kadar fosfor dan kalsium dan mengurangi kehilangan tulang pada tikus yang diovariektomi (Shalaby et al. 2011).

\subsection{Anti Kanker}

Kanker merupakan salah satu penyakit berat yang pengobatannya dilakukan dalam jangka waktu lama. Berbagai pendekatan dilakukan untuk pengobatan kanker termasuk penggunaan bahan alam. Bahan alam yang digunakan untuk mengatasi kanker merupakan senyawa yang mampu merusak sel kanker namun tidak pada sel normal atau senyawa yang mampu merangsang apostosis. Ekstrak kulit buah CA 6 $\mu \mathrm{g} / \mathrm{mL}$ menginduksi apoptosis dan akumulasi sel pada fase G1, sedangkan CPE $15 \mu \mathrm{g} / \mathrm{mL}$ menginduksi apoptosis dan akumulasi sel pada fase G2/M. Kombinasi doxorubicin $200 \mathrm{nM}$ dengan ekstrak kulit buah CA $6 \mu \mu \mathrm{g} / \mathrm{mL}$ meningkatkan induksi apoptosis dan akumulasi sel pada fase $\mathrm{G} 2 / \mathrm{M}$ dari pada pemberian secara tunggal. Pemberian ekstrak hanya CA dan kombinasi ekstrak kulit buah CA dan doxorubicin mampu meningkatkan apoptosis sel MCF-7 yang terbukti dari meningkatnya ekspresi protein p53 dan Bcl-2. Hal tersebut menunjukkan bahwa ekstrak kulit buah CA dapat dikembangkan sebagai agen co-kemoterapi dengan doxorubicin pada sel kanker payudara (Adina et al. 2012).

\section{KESIMPULAN}

Secara etnobotani Citrus aurantifolia digunakan untuk mengatasi demam, bahan sauna, obat batuk, untuk meningkatkan stamina, mengatasi hipertensi, dan anti kolesterol. Bioaktivitas Citrus aurantifolia yaitu anti kolesterol, anti mikroba, antioksidan, anti hipertensi, anti osteoporosis dan anti kanker.

\section{DAFTAR PUSTAKA}

Adina, A., Goenadi, F., Handoko, F.F. Nawangsari, D., Hermawan, A., Jenie, R., et al. (2014). Combination of ethanolic extract of Citrus aurantifolia peels with doxorubicin modulate cell cycle and increase apoptosis induction on MCF-7 cells.Combination of ethanolic extract of Citrus aurantifolia peels with doxorubicin modulate cell cycle and incre. Iranian Journal of Pharmaceutical Research, 13 (3) , 919-926.

Aibinu, I., Adenipekun, T., Adelowotan, T., Ogunsanya, T., \& Odugbemi, T. 
(2007). Evaluation of the antimicrobial properties of different parts of Citrus aurantifolia (lime fruit) as used locally. Afr. J. Trad. CAM, 4(2), 185- 190.

Chunlaratthanaphorn, S., Lertprasertsuke, N., Srisawat, U., Thuppia, A., N. A., Suwanlikhid, N., et al. (2007). Acute and subchronic toxicity study of the water extract from root of Citrus aurantifolia (Christm. et Panz.) Swingle in rats. Songklanakarin. J. Sci. Technol., 29 (Suppl. 1) , 125-139.

Craske, J.D., Suryadi, N., and M Wootton. (2005). A comparison of the peel oil components of Australian native lime (Microcitrus australe) and Mexican lime (Citrus aurantifolia Swingle). J Sci Food Agric 85:522-525.

Halliwell, B. (1996). Antioxidants in human health and disease. Annu Rev. Nutr. 16: 33-50.

Kumari, S., Sarmah, N., Handique, A.K. (2013). Antioxidant activities of the unripen and ripen Citrus aurantifolia of Assam. International Journal of Innovative Research in Science, Engineering and Technology 2(9): 4812-4816

Kumar, M., Parthiban, S., Saraladevi, D., Ponnuswami, V. (2013). Genetic diversity analysis of acid lime (Citrus aurantifolia Swingle) cultivars. The Bioscan 8(2): 481484.

Loizzo, M., Tundis, R., Bonesi, M., Menichini, F., De Luca, D., Colicad, C., et al. (2012). Evaluation of Citrus aurantifolia peel and leaves extracts for their chemical composition, antioxidant and anti-cholinesterase activities. $J$. Sci. Food Agric. 92: 2960-2967.

Onyeagba, R.A., Ugbogu, O.C., Okeke, C.U., Iroakasi, O. (2004). Studies on the antimicrobial effects of garlic (Allium sativum Linn), ginger
(Zingiber officinale Roscoe) and lime (Citrus aurantifolia Linn). African Journal of Biotechnology 3(10): 552-554.

Oboh, G., Bello, F.O., Ademosun, A.O., Akinyemi, A.J., Adewuni, T.M. (2015). Antioxidant, hypolipidemic, and anti-angiotensin-1converting enzyme properties of lemon (Citrus limon) and lime (Citrus aurantifolia) juices. Comp. Clin. Pathol. 24: 1395-1406.

Oboh, P.A., Abulu E.O. (1997). The antimicrobial activities of extracts of Psidium guajava and Citrus aurintifolia. Nig. J. Bioctechn. 8(1): 25.

Okwu, D.E., Emenike, I.N. (2006). Evaluation of the phytonutrients and vitamins content of citrus fruits. International Journal of Molecular Medicine and Advance Sciences 2(1): 1-6.

Razak, A., Djamal, A., Revilla, G. (2013). Uji daya hambat air perasan buah jeruk nipis (Citrus aurantifolia) terhadap pertumbuhan bakteri Staphylococcus aureus secara in vitro. Jurnal Kesehatan Andalas 2(1): 5-8.

Silalahi, M. (2014). The ethnomedicine of the medicinal plants in subethnic Batak, North Sumatra and the conservation perspective, Dissertation. Indonesia: Universitas Indonesia.

Silalahi, M., Nisyawati, Walujo, E.B. and Supriatna, J. (2015) Local knowledge of medicinal plants in sub-ethnic Batak Simalungun of North Sumatra, Indonesia. Biodiversitas 16(1): 44-54.

Silalahi, M., Nisyawati. (2019). An ethnobotanical study of traditional steam-bathing by the Batak people of North Sumatra, Indonesia. Pacific Conservation Biology 25 (3): 266-282. 
Sandoval-Montemayor, N., García, A., Elizondo-Treviño, E., GarzaGonzález, E., Alvarez, L., \& Camacho-Corona, M. (2012). Chemical composition of hexane extract of Citrus aurantifolia and anti Mycobacterium tuberculosis activity of some of its constituents. . Molecules 17, 11173-11184.

Shalaby, N.M.M., Abd-Alla, H.I., Ahmed, H.H., Basoudan, N. (2011). Protective effect of Citrus sinensis and Citrus aurantifolia against osteoporosis and their phytochemical constituents. Journal of Medicinal Plants Research 5(4): 579-588.

Taiz, L., Zeiger, E. (2006). Plant Physiology. Sinauer Associates, Inc, Sunderland: xxvi $+764 \mathrm{hlm}$.

Taiwo, S.S, Oyekanmi, B.A., Adesiji, Y.O., Opaleye, O.O., Adeyeba, O.A. (2007). In vitro antimicrobial activity of crude extractof Citrus aurintifolia Linn and Tithonia diversifolia Poaceae on clinical bacterial isolates. Internastional Journal of Tropical Medicine 2(4): 113-117.

Yaghmaie, P., Parivar, K., Haftsavar, M. (2011). Effects of Citrus aurantifolia peel essential oil on serum cholesterol levels in Wistar rats. Journal of Paramedical Sciences 2(1): 29-33.

Zhang, D., Mabberley, D.J. (2008). Citrus. Dalam: Wu, Z.Y., Raven P.H., Hong, D.Y. (eds). Flora of China vol. 11 (Oxalidaceae through Aceraceae). Beijing: Sci Pr dan St. Louis: Missouri Bot Gard Pr. pp 89-96. 